\title{
Tính mùa vụ và giải pháp marketing cho phát triển bền vững du lịch biển Đồ Sơn
}

\author{
Vũ Trí Dũng*, Phạm Thị Kim Thanh \\ Đại học Kinh tế Quốc dân, 207 Giải Phóng, Hai Bà Trung, Hà Nội, Việt Nam \\ Nhận ngày 26 tháng 3 năm 2017 \\ Chỉnh sửa ngày 15 tháng 6 năm 2017; Chấp nhận đăng ngày 28 tháng 6 năm 2017
}

\begin{abstract}
Tóm tắt: Du lịch biển là lĩnh vực kinh tế có vị trí quan trọng ở Việt Nam. Do chịu sự ảnh hưởng bởi điều kiện khí hậu nhiệt đới gió mùa có một mùa đông lạnh, nên hoạt động du lịch biển ở các tỉnh phía Bắc thường mang tính mùa vụ và gặp phải những khó khăn đáng kể so với các tỉnh phía Nam. Tính mùa vụ của hoạt động du lịch nói chung, du lịch biển nói riêng đã nhận được nhiều sự quan tâm từ các những nhà quản lý và kinh doanh du lịch cũng như các nhà khoa học. Việc nghiên cứu làm rõ về bản chất, nguyên nhân hình thành, hướng tác động cũng như các giải pháp nhằm giảm thiểu những tác động bất lợi của tính mùa vụ tới hoạt động du lịch luôn có tính cấp thiết và ý nghĩa khoa học.

Bài viết này tập trung phân tích và đánh giá những ảnh hưởng của tính mùa vụ tới hoạt động kinh doanh du lịch biển ở Đồ Sơn, thành phố Hải Phòng. Trên cơ sở đó, nhóm tác giả đề xuất các giải pháp marketing theo tiếp cận điều tiết cầu và điều tiết cung, trong dài hạn và ngắn hạn để khắc phục những tác động tiêu cực của tính thời vụ mang lại.
\end{abstract}

Tù khóa: Marketing du lịch, tính mùa vụ, dịch vụ du lịch, Đồ Sơn.

\section{1. Đặt vấn đề}

Nói tới du lịch Hải Phòng, không thể không nói tới Đồ Sơn - điểm du lịch nổi tiếng với cảnh quan thiên nhiên đặc sắc, hữu tình, với các bãi tắm rộng, bờ cát mịn trải dài và những hàng thông xanh ngày đêm vi vút. Trong những năm gần đây, do chất lượng cuộc sống được cải thiện, nhu cầu du lịch của người dân tăng lên, du khách trong nước và quốc tế đến với Đồ Sơn có xu hướng gia tăng đáng kể. Tuy nhiên, cũng như nhiều điểm du lịch khác ở Bắc Bộ, trong điều kiện khí hậu nhiệt đới ẩm gió mùa, chịu ảnh hưởng sâu sắc của gió mùa đông bắc vào

\footnotetext{
*Tác giả liên hệ. ĐT.: 84-913535950.

Email: vtdung@cfvg.org

https://doi.org/10.25073/2588-1094/vnuees.4091
}

mùa đông, du lịch biển Đồ Sơn bị hạn chế lớn là có tính mùa vụ cao, tập trung chủ yếu vào mùa hè. Thực tế này gây nhiều khó khăn cho phát triển du lịch do doanh thu chủ yếu chỉ vào mùa hè; khó khăn cho chính khách du lịch lúc chính vụ do lượng khách tập trung quá đông, khả năng phục vụ không đáp ứng nồi.

Hoạt động kinh doanh du lịch biển Đồ Sơn bị ảnh hưởng sâu sắc bởi tính mùa vụ đang là vấn đề cấp thiết đặt ra cho các nhà quản lý, hoạch định chính sách và các doanh nghiệp trên địa bàn. Việc xác định được những yếu tố chính của hiện tượng này, để đề xuất được các biện pháp hạn chế những tác động tiêu cực của tính mùa vụ là cơ sở quan trọng cho phát triển $\mathrm{du}$ lịch biển Đồ Sơn. 


\section{Cơ sở lý luận và phương pháp nghiên cứu}

\subsection{Tính mùa vụ trong hoạt động du lịch}

Hiện tượng hoạt động du lịch lặp đi lặp lại khá đều đặn vào một số thời điểm trong năm được gọi là tính mùa vụ hay thời vụ du lịch. Tính mùa vụ du lịch cản trở tiến trình bình thường của hoạt động du lịch trong năm và gây ra hàng loạt những ảnh hưởng tiêu cực về kinh tế, xã hội, tổ chức và kỹ thuật. Commons and Page (2001) gợi ý rằng tính mùa vụ liên quan đến du lịch gắn liền với du lịch và thực tế là các luồng du lịch được xác định bởi các yếu tố mang tính chất tạm thời và theo mùa [1]. Manning and Powers (1984) nắm bắt được bản chất của vấn đề trong phần sau đây giải thích tính mùa vụ và các tác động tiêu cực của nó: "Việc sử dụng không đều theo thời gian (peaking) là một trong những vấn đề phổ biến nhất đối với hoạt động giải trí ngoài trời và $\mathrm{du}$ lịch ngoài trời, gây ra việc sử dụng tài nguyên không hiệu quả, mất lợi nhuận, căng thẳng về năng lực vận chuyển sinh thái và xã hội". Các tác giả cũng lo ngại rằng các cơ sở và dịch vụ có thể không được tận dụng hết, tuy nhiên, họ cũng lưu ý đến những hàm ý của việc sử dụng quá nhiều thiết bị, cho thấy các điểm đến và các nhà khai thác có thể phải đối mặt với sự không hiệu quả liên tục khi họ phải vật lộn với tính mùa vụ và những thời điểm tập trung cao độ của nhu cầu du lịch [2].

Ở Việt Nam, "Tính mùa vụ trong hoạt động du lịch" là một trong những chủ đề được quan tâm cả về phương diện học thuật và thực tiễn, song các công trình nghiên cứu riêng cho vấn đề này không nhiều, chủ yếu được lồng ghép trong các nghiên cứu chung về du lịch. Nghiên cứu một cách hệ thống nhất về tính mùa vụ trong hoạt động du lịch được thực hiện bởi Viện Nghiên cứu và Phát triển du lịch, Tổng cục $\mathrm{Du}$ lịch với đề tài "Nghiên cứu ảnh hưởng của tính mùa vụ du lịch đến hoạt động du lịch ở Việt Nam". Kết quả nghiên cứu của đề tài cho thấy: (i) Hoạt động du lịch của nước ta bị ảnh hưởng bởi tính mùa vụ du lịch trên bình diện quốc gia nói chung và các điểm du lịch nói riêng. Điều này đang làm đau đầu các nhà quản lý, hoạch định chính sách và các nhà doanh nghiệp. (ii) Vấn đề đặt ra là xác định được những yếu tố chính của hiện tượng này làm cơ sở cho việc đề xuất các biện pháp hạn chế những tác động tiêu cực đến hoạt động du lịch [3]. Một số các công bố khác cũng được đăng tải trên Website như "Du lịch miền Trung: Tìm cách phá thế mùa vụ" [4], "Du lịch biển: Khắc phục tính thời vụ do tác động của khí hậu" (http://vietnamtourism.gov.vn/index.php/items/ 18483), "Khắc phục tính thời vụ của du lịch" (http://www.baobariavungtau.com.vn/dulich/201602/khac-phuc-tinh-thoi-vu-cua-dulich-663776/),...

Tính mùa vụ du lịch là một tồn tại khách quan, nó xuất hiện khắp mọi nơi trên thế giới. Mùa vụ du lịch hình thành do nhiều nguyên nhân rất đa dạng với cơ chế tác động phức tạp: có nguyên nhân tự nhiên, có nguyên nhân kinh tế - xã hội, tổ chức kỹ thuật, có nguyên nhân mang tính cá nhân. Một số nguyên nhân tác động chủ yếu lên cầu du lịch, số khác tác động chủ yếu vào cung, có những nguyên nhân tác động lên cả cung và cầu du lịch. Nguyên nhân tự nhiên, trong đó yếu tố khí hậu tại điểm du lịch đóng vai trò quan trọng nhất. Việc nghiên cứu về tính mùa vụ du lịch cho thấy: cường độ, độ dài và tần số của mùa du lịch ở một lãnh thổ nào đó có sự thay đổi theo thời gian. Sự khác biệt về cường độ, độ dài và tần số của mùa du lịch sẽ dẫn đến sự khác biệt về mức độ ảnh hưởng của mùa vụ du lịch đối với hoạt động du lịch. Tính mùa vụ du lịch tại một đơn vị lãnh thổ nào đó là tập hợp các biến động có tính chu kỳ theo thời gian trong năm của cung và cầu du lịch. Tính mùa vụ trong hoạt động du lịch được xác định bởi số thời gian thích hợp nhất trong năm của các điều kiện khí hậu, thời tiết đối với sức khỏe của du khách và số thời gian trong năm thuận lợi nhất cho việc triển khai các hoạt động du lịch.

Tính mùa vụ du lịch ở một khu vực là sự dao động có tính chu kỳ trong năm của mối quan hệ cung và cầu du lịch xảy ra dưới tác động của cùng một nhóm các yếu tố tác động. Sự khác biệt của thời gian tác động và các chỉ số về sự xuất hiện của mỗi loại là nguyên nhân 
dẫn đến sự dao động trong toàn bộ các hoạt động du lịch.

Tính mùa vụ thường có ảnh hưởng tiêu cực đối với ngành du lịch nói chung và ảnh hưởng đến sự phát triển kinh tế xã hội của các địa phương - nơi có hoạt động du lịch diễn ra nói riêng. Tính mùa vụ của tài nguyên du lịch ảnh hưởng trực tiếp đến hướng khai thác, đầu tư, quy hoạch, kinh doanh du lịch, được đánh giá cho tài nguyên tự nhiên và nhân văn. Tính mùa vụ tác động đến tất cả các thành phần của quá trình hoạt động du lịch như tài nguyên du lịch, cơ sở vật chất kỹ thuật phục vụ du lịch, lao động trong du lịch và cả khách du lịch. Mùa du lịch ngắn là nguyên nhân của việc phần lớn các cơ sở vật chất kỹ thuật cũng như lao động chuyên ngành chỉ được sử dụng có hiệu quả trong một quãng thời gian nhất định trong năm, dẫn đến việc tăng chi phí cố định và giá thành của hàng hoá, dịch vụ. Điều này làm giảm khả năng xây dựng một chính sách giá mềm dẻo, gây khó khăn cho công tác tổ chức và giảm khả năng cạnh tranh. Không những thế, nó còn hạn chế các khả năng của du khách trong việc tìm ra một điểm đến thích hợp trong thời gian mong muốn. Tính mùa vụ còn đem lại sự tập trung cao của du khách trong một thời gian nhất định đối với các phương tiện vận chuyển, gây ách tắc giao thông ở các điểm du lịch, làm mất đi sự tiện lợi trong quá trình di chuyển, lưu trú, làm giảm chất lượng phục vụ và tạo nên sức ép về môi trường đối với các tài nguyên du lịch.

Có thể khắc phục, hạn chế tác động tiêu cực của tính mùa vụ do điều kiện tự nhiên mang lại cho mỗi điểm du lịch bằng việc quy hoạch, tổ chức phát triển du lịch một cách hợp lý. Một điểm du lịch có thể có một hoặc nhiều mùa vụ du lịch tuỳ thuộc vào khả năng đa dạng hoá các loại hình du lịch ở đó: (i) Mùa du lịch chính: là khoảng thời gian có cường độ tiếp nhận khách du lịch lớn nhất, trong giai đoạn này số lượng khách khá ổn định; (ii) Thời kỳ đầu mùa và cuối mùa chính: là thời kỳ có cường độ du lịch nhỏ hơn ngay trước mùa chính (đầu mùa) và ngay sau mùa chính (cuối mùa) và (iii) Ngoài mùa du lịch chính: là khoảng thời gian có cường độ thu hút khách du lịch thấp nhất.

\subsection{Khái quát về marketing du lịch}

Marketing là quá trình liên tục, nối tiếp nhau qua đó bộ phận marketing của các doanh nghiệp kinh doanh du lịch lập kế hoạch, nghiên cứu, thực hiện, kiểm soát, đánh giá các hoạt động nhằm thoả mãn nhu cầu mong muốn của khách hàng và đạt được những mục tiêu của công ty. Marketing du lịch là một loại phương pháp và kỹ thuật được hồ trợ bằng một tinh thần đặc biệt và có phương pháp nhằm thoả mãn các nhu cầu của khách hàng, có thể là mục đích tiêu khiển hoặc những mục đích khác [5].

Những đặc tính hoàn toàn khác biệt của dịch vụ bao gồm: tính vô hình, tính không đồng nhất, không thể tách rời được, khó kiểm soát chất lượng,...nên marketing mix dịch vụ bao gồm 7P: Sản phẩm (product); Giá (price); Phân phối (place); Truyền thông (promotion); Con người (People); Quy trình (process) và Môi trường dịch vụ (Physical) [6].

\subsection{Phuoong pháp nghiên cưu}

Để có thể phân tích và đánh giá tác động của tính thời vụ đến hoạt động du lịch Đồ Sơn, ngoài các phương pháp điều tra, khảo sát ngoài thực địa, phương pháp điều tra xã hội học, tác giả đã sử dụng phương pháp phân tích, tổng hợp tài liệu. Do tính thời vụ là nhân tố khách quan nên phương pháp thống kê, tổng hợp sẽ cho phép xác định tần suất và mức độ ảnh hưởng đến hoạt động du lịch nói chung và $d u$ lịch biển ở các tỉnh phía bắc nói riêng. Phương pháp này cũng đưa ra những nhận định, đánh giá thực trạng về du khách và các giải pháp marketing nhằm giảm thiểu tính thời vụ đối với $\mathrm{du}$ lịch Đồ Sơn.

\section{Kết quả nghiên cứu}

3.1. Các yếu tố ảnh hưởng tới hoạt động du lịch và tạo nên tính mùa vu của du lịch biển Đồ Sơn

\section{- Tài nguyên du lịch của Đồ Sơn}

Đồ Sơn là một đơn vị hành chính trực thuộc thành phố Hải Phòng. Nền kinh tế quận Đồ Sơn luôn phát triển và tăng trưởng cao theo từng 
năm, trong đó du lịch là một lĩnh vực chủ yếu, chiếm tới 70\% trong GDP của quận [7].

Đồ Sơn là khu du lịch nổi tiếng với bãi biển trải dài, các di tích và danh thắng hoà quyện trong không gian thơ mộng của núi - biển - mây trời, làm say lòng du khách bốn phương.

Các bãi biển ở Đồ Sơn khá đẹp, cát mịn, ít vỏ sò, hàu, có độ nghiêng thoải và sóng không quá lớn, tạo cảm giác an toàn và dễ chịu đối với du khách. Nơi đây còn có sự kết hợp giữa một bên là núi non, với hàng ngàn cây phi lao, thông, cọ,... còn một bên là biển cả mênh mông đỏ màu phù sa tạo nên một phong cảnh "non nước hữu tình". Bãi tắm của Đồ Sơn chia ra làm 3 khu chính: Khu 1 nằm ngay đầu của quận Đồ Sơn; Khu 2 ở giữa có nhiều khách sạn hiện đại, cao cấp; và Khu 3 khá yên tĩnh, kín đáo nằm xa nhất về phía Nam của bán đảo Đồ Sơn.

Tài nguyên du lịch nhân văn là những tài nguyên mà con người tạo ra để phục vụ du lịch và tạo nên giá trị văn hóa của Quận Đồ Sơn, là giá trị của sự sáng tạo văn hóa được kết tinh lại và có sức thu hút cao. Trên địa bàn Quận Đồ Sơn có $30 \mathrm{di}$ tích, danh thắng trong đó có $5 \mathrm{di}$ tích Quốc gia: Tháp Tường Long, Đình Ngọc Xuyên, Bến tàu Không số (K15), Bến Nghiêng, Đảo Dáu. Có đền Bà Đế là một trong những đền nổi tiếng về danh thắng và linh thiêng.Đồ Sơn cũng có một số lễ hội nổi tiếng toàn quốc, như Lễ hội chọi Trâu Đồ Sơn, Hội thi bơi thuyền Rồng trên biển, Lễ hội Đền Bà Đế, Lễ hội Hòn Dáu.

Đồ Sơn còn có các sản phẩm văn hoá truyền thống phong phú của người miền biển Hải Phòng như hát Đúm, các phong tục tập quán, các chợ quê, các làng nghề,... Văn hoá âm thực của Đồ Sơn cũng khá phong phú: rau muống giòn, thịt trâu chọi Đồ Sơn, nộm sứa, bánh đa cua bể...

Các khu du lịch nổi tiếng ở Đồ Sơn phải kể tới có: Khu du lịch đảo Dáu với bể bơi nhân tạo thuộc hàng lớn nhất Châu Á, có vườn chim, vườn thú, khu vui chơi giải trí, các khách sạn đẳng cấp 3 đến 5 sao, đặc biệt không thể thiếu ngọn hải đăng cổ kính hơn trăm năm tuổi. Đây còn được gọi vui bằng cái tên "Đà Lạt thu nhỏ"; Khu du lịch Đồ Sơn còn vinh dự là nơi có hòn đảo nhân tạo đầu tiên của Việt Nam - đảo Hoa Phượng, toạ lạc tại trung tâm khu du lịch, được trang bị đầy đủ các tiện nghi hiện đại cực kỳ sang trọng: trung tâm thương mại cao cấp ở giữa đảo, bể bơi nhân tạo,phố ăn uống, khách sạn đẳng cấp 5 sao, khu biệt thự, bến du thuyền,... là nơi lý tưởng để khách du lịch đến dừng chân và nghỉ dưỡng.

\section{- Điều kiện khí hậu}

Khí hậu Đồ Sơn, Hải Phòng mang đặc điểm chung miền ven biển vịnh Bắc Bộ với 4 mùa rõ rệt là Xuân, Hạ, Thu, Đông. Khí hậu ở đây mang tính chất cận nhiệt đới ẩm với mùa hè nóng ẩm, mưa nhiều và mùa đông khô, lạnh. Nhiệt độ trung bình mùa hè vào tháng 7 là $28,3^{\circ} \mathrm{C}$, tháng lạnh nhất là tháng 1 với nhiệt độ $16,3^{\circ} \mathrm{C}$. Từ tháng 4 đến tháng 10 là mùa du lịch tại Đồ Sơn vì lúc này là thời tiết nắng nóng. Mùa đông rơi vào tháng 11 đến tháng 3 năm sau, thời tiết lạnh nên rất ít khách du lịch đến Đồ Sơn vào thời điểm này (https://matran.vn/dia-ly/vi-tri-dia-hinh-thuyvan-va-khi-hau-hai-phong-34.html).

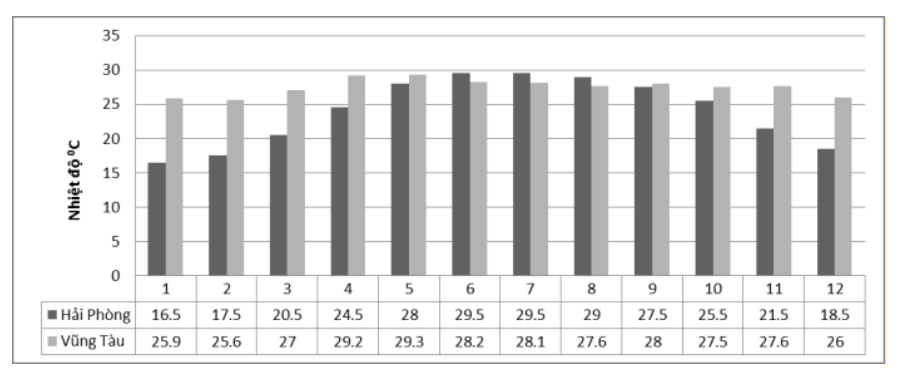

Hình 1. Nhiệt độ không khí trung bình các tháng tại Hải Phòng, Vũng Tàu $\left({ }^{\circ} \mathrm{C}\right)$. 
Trong khi đó, Bà Rịa - Vũng Tàu nằm trong vùng nhiệt đới gió mùa, chịu ảnh hưởng của đại dương . Nhiệt độ trung bình khoảng $27^{\circ} \mathrm{C}$; sự thay đổi nhiệt độ của các tháng trong năm không lớn. Số giờ nắng trong năm dao động trong khoảng $2.370-2.850$ giờ và phân phối đều các tháng trong năm, theo đó, mùa du lịch kéo dài cả năm (hình 1 ).

\subsection{Biểu hiện của tính mùa vư trong hoạt động du lịch tại khu du lịch biển Đồ Sơn}

Tổng hợp lượng khách du lịch đến khu du lịch Đồ Sơn trong những năm gần đây cho thấy rất rõ tính mùa vụ với cường độ mạnh và thời gian rất ngắn của du lịch Đồ Sơn. Mặc dù tài nguyên hấp dẫn và cơ sở hạ tầng đã được đầu tư nâng cấp khá tốt, nhưng Đồ Sơn chỉ thu hút được khách trong 4 tháng là $5,6,7,8$. Khách đặc biệt đông vào tháng 6 và tháng 7 , chiếm khoảng 60\% lượng khách cả năm. Các tháng còn lại trong năm thì lượng khách giảm mạnh, thậm chí một số tháng không có khách (bảng 1).

Hiện tại, khách về nghỉ tại Đồ Sơn với mục đích chủ yếu là du lịch tắm biển. Các loại hình ít phụ thuộc vào thời tiết như du lịch công vụ (du lịch MICE), du lịch chữa bệnh, tổ chức sự kiện... vẫn chưa phát triển mạnh. Vì vậy, tuy lượng khách về Đồ Sơn rất đông nhưng mang tính mùa vụ cao, lượng khách không ổn định trong năm mà chỉ tập trung vào một số tháng trong năm.

Tính mùa vụ có ảnh hưởng tiêu cực đến hoạt động du lịch của Đồ Sơn xét trên nhiều khía cạnh, như: (i) hiệu quả khai thác cơ sở vật chất kỹ thuật du lịch, (ii) tài nguyên và môi trường du lịch biển, iii) nguồn nhân lực du lịch Đồ Sơn và (iv) mức độ hài lòng của khách du lịch.

Đặc điểm của tính mùa vụ ở loại hình du lịch tắm biển kết hợp nghỉ dưỡng ở các khu du lịch biển Việt Nam là tương đối giống nhau. Song, do đặc điểm vị trí địa lý, địa hình dẫn đến sự phân hoá điều kiện khí hậu nên mùa vụ ở các điểm du lịch biển Việt Nam có sự khác nhau về thời gian, độ dài và cả tính chất, dẫn đến ảnh hưởng của mùa vụ đến hoạt động du lịch cũng có đôi chút khác.

Để tìm ra nguyên nhân thực sự có tác động mạnh đến tính mùa vụ du lịch biển Đồ Sơn, có thể so sánh mức độ tác động của các yếu tố tác động tạo tính mùa vụ ở hai khu du lịch đó là khu du lịch Đồ Sơn và khu du lịch Vũng Tàu (Bà Rịa - Vũng Tàu).

Bảng 1. Sự biến động lượng khách theo các tháng trong năm từ 2012 - 2016.

Đơn vị tính : Nghìn luợt người

\begin{tabular}{|c|c|c|c|c|c|c|c|}
\hline Chỉ tiêu & Tháng & 4 & 5 & 6 & 7 & 8 & 9 \\
\hline \multirow{2}{*}{2012} & Lượt khách & 59 & 594 & 976 & 983 & 618 & 67 \\
\hline & Tỉ lệ \% & $1.79 \%$ & $18.02 \%$ & $29.60 \%$ & $29.81 \%$ & $18.74 \%$ & $2.03 \%$ \\
\hline \multirow{2}{*}{2013} & Lượt khách & 71 & 665 & 1115 & 1213 & 620 & 70 \\
\hline & Tỉ lệ \% & $1.89 \%$ & $17.71 \%$ & $29.70 \%$ & $32.31 \%$ & $16.52 \%$ & $1.86 \%$ \\
\hline \multirow{2}{*}{2014} & Lượt khách & 76 & 715 & 1189 & 1303 & 666 & 75 \\
\hline & Tỉ lệ \% & $1.90 \%$ & $17.75 \%$ & $29.54 \%$ & $32.39 \%$ & $16.55 \%$ & $1.87 \%$ \\
\hline \multirow{2}{*}{2015} & Lượt khách & 89 & 768 & 1378 & 1401 & 716 & 81 \\
\hline & Tỉ lệ \% & $2.01 \%$ & $17.32 \%$ & $31.09 \%$ & $31.60 \%$ & $16.15 \%$ & $1.82 \%$ \\
\hline \multirow{2}{*}{2016} & Lượt khách & 106 & 835 & 1581 & 1605 & 769 & 87 \\
\hline & Tỉ lệ \% & $2.13 \%$ & $16.76 \%$ & $31.73 \%$ & $32.21 \%$ & $15.44 \%$ & $1.74 \%$ \\
\hline
\end{tabular}

(Nguồn: Tính theo số liệu của Phòng du lịch thuoong mại UBND Quận Đồ Sơn) [7] 
Bảng 2. Bảng tổng hợp tỷ lệ lượng khách du lịch các tháng trong năm (\%)

\begin{tabular}{|c|c|c|c|c|c|c|c|c|c|c|c|c|c|}
\hline Địa danh & Tháng & 1 & 2 & 3 & 4 & 5 & 6 & 7 & 8 & 9 & 10 & 11 & 12 \\
\hline \multirow[t]{2}{*}{ Đồ Sơn } & 2015 & 0 & 0 & 0 & 2.01 & 17.32 & 31.09 & 31.60 & 16.15 & 1.82 & 0 & 0 & 0 \\
\hline & 2016 & 0 & 0 & 0 & 2.13 & 16.76 & 31.73 & 32.21 & 15.44 & 1.74 & 0 & 0 & 0 \\
\hline Vũng & 2015 & 8.5 & 11 & 8 & 7.5 & 10 & 5.8 & 7.5 & 10.2 & 7.5 & 5.5 & 6.5 & 12 \\
\hline Tàu & 2016 & 7.5 & 9.5 & 11 & 7 & 9.5 & 6.5 & 6 & 10 & 7 & 6.5 & 8.5 & 11 \\
\hline
\end{tabular}

(Nguồn: Tính theo số liệu của Phòng du lịch thuoong mại UBND Quận Đồ Sơn và TP Vũng Tàu)

Bảng 3. Mức độ ảnh hưởng của các yếu tố tác động đến tính mùa vụ du lịch biển

\begin{tabular}{|c|c|c|c|c|c|c|c|}
\hline \multicolumn{2}{|c|}{ Yếu tố tác động } & \multicolumn{3}{|c|}{ Nhóm yếu tố tự nhiên } & \multicolumn{3}{|c|}{ Nhóm yếu tố kinh tế xã hội } \\
\hline Loại hình & lịch & $\begin{array}{l}\text { Yếu tố } \\
\text { khí hậu }\end{array}$ & $\begin{array}{l}\text { Yếu tố } \\
\text { địa hình }\end{array}$ & $\begin{array}{c}\text { Yếu tố } \\
\text { tự nhiên } \\
\text { khác }\end{array}$ & $\begin{array}{l}\text { Phong tục } \\
\text { tập quán }\end{array}$ & $\begin{array}{l}\text { Thời gian } \\
\text { rỗi }\end{array}$ & $\begin{array}{l}\text { Yếu tố xã } \\
\text { hội khác }\end{array}$ \\
\hline \multirow{2}{*}{$\begin{array}{l}\text { Tắm biển kết hợp } \\
\text { nghỉ dưỡng biển }\end{array}$} & Đồ Sơn & $\uparrow$ & - & $\downarrow$ & - & $\rightarrow$ & $\downarrow$ \\
\hline & Vũng Tàu & $\downarrow$ & - & $\downarrow$ & - & $\uparrow$ & $\downarrow$ \\
\hline
\end{tabular}

- $\quad \uparrow$ : Mức độ ảnh hưởng mạnh

- $\quad \downarrow$ : Mức độ ảnh hưởng yếu

Cùng là khu du lịch biển, nhưng tính mùa vụ ở khu du lịch Vũng Tàu không sâu sắc và rõ nét như khu du lịch Đồ Sơn. Trong khi ở Đồ Sơn chỉ có khách du lịch trong khoảng thời gian từ tháng 4 đến tháng 9 , tập trung chủ yếu từ tháng 5 đến tháng 8 , thì ở Vũng Tàu lượng khách đến được dải đều toàn bộ các tháng trong năm (bảng 2).

So sánh mức độ ảnh hưởng của các yếu tố tác động đến tính mùa vụ du lịch biển cho thấy yếu tố khí hậu, sau đó là yếu tố thời gian rỗi có mức độ tác động mạnh nhất tới du lịch biển ở Đồ Sơn, trong khi du lịch biển ở Vũng Tàu chỉ chịu tác động mạnh bởi một yếu tố là thời gian rồi (bảng 3).

Khi đã nắm bắt được những nguyên nhân gây ra tính mùa vụ du lịch, có thể tìm ra khả năng tác động vào tính mùa vụ du lịch nhằm điều tiết mùa vụ du lịch cao điểm và thấp điểm, hạn chế những tác động bất lợi của nó trong du lịch và các ngành liên quan đến du lịch.

\subsection{Thưc trạng marketing trong hoạt động $d u$ lịch biển Đồ Sơn}

Các hoạt động marketing được thực hiện theo 2 hướng là tác động đến cầu (giá và truyền

\footnotetext{
$\rightarrow$ : Mức độ ảnh hưởng trung bình

- : Không có ảnh hưởng
}

thông marketing) và đến cung thị trường (sản phẩm, kênh phân phối, con người, môi trường du lịch...).

Các doanh nghiệp kinh doanh dịch vụ tại Quận Đồ Sơn đã dựa theo quy luật mùa vụ để định mức giá vào từng thời điểm khác nhau, tuy nhiên do hoạt động kinh doanh du lịch ở Đồ Sơn mang tính mùa vụ rõ rệt nên mức giá chênh lệch giữa mùa chính vụ và trái vụ là quá lớn, thậm chí có lúc gấp 2, 3 lần so với thời kỳ thấp điểm.

Trên địa bàn Đồ Sơn hiện có trên 250 nhà nghỉ, khách sạn nhưng việc quảng cáo cho sản phẩm của các doanh nghiệp còn rất hạn chế. Các doanh nghiệp chưa chú trọng đến việc xây dựng các trang Web để quảng cáo cho sản phẩm dịch vụ của mình, vì vậy rất khó có thể để khách du lịch tìm kiếm thông tin. Mặc dù Đồ Sơn có một số lượng lớn các khách sạn, nhà hàng có khả năng phục vụ khách quốc tế. Tuy nhiên, mới chỉ có khoảng 10 nhà hàng nằm trong hệ thống khách sạn đạt tiêu chuẩn 2 sao trở lên như: Resort Hòn Dáu, khách sạn Đồ Sơn, Hoa Phượng, Vạn Thông, Hải Âu, Công Đoàn... Nhưng chỉ có một số rất ít nhà hàng 
cung cấp dịch vụ ăn uống có chất lượng đáp ứng được yêu cầu của khách châu Âu [8].

Mức độ đầu tư hàng năm để nâng cấp cơ sở du lịch cũng không cao. Do tư tưởng "làm 3 tháng ăn 1 năm" nên các hộ kinh doanh hầu như chưa chú ý đến vấn đề khai thác du lịch bền vững, đầu tư nâng cấp... mà chỉ chú ý đến vấn đề tận thu trong mùa vụ. Hơn nữa, kiến trúc kiốt nhà hàng còn đơn giản, trang thiết bị phục vụ du khách ăn uống còn bình dân, chưa tạo được nét đặc thù và có chất lượng cao để có thể tăng thêm sức hấp dẫn cho trung tâm du lịch Đồ Sơn.

Các công ty du lịch trọn gói, đơn vị tổ chức tour thường có quan hệ rất mật thiết với các khách sạn qua việc ký kết hợp đồng cung cấp dịch vư lưu trú. Một số công ty, khách sạn lớn cũng tổ chức tour và phân phối vé cho các hãng đại lý bán. Tuy nhiên việc liên kết này cũng chưa chặt chẽ và bền vững. Công tác nghiên cứu thị trường cũng được thực hiện nhưng chỉ diễn ra vào thời điểm trước tháng 4 hàng năm (tháng bắt đầu mùa du lịch Đồ Sơn).

Trong những năm gần đây, du lịch Đồ Sơn được đầu tư hàng chục công trình, cả về du lịch (cơ sở lưu trú, nhà hàng, khu vui chơi, giải trí...) và công cộng (hệ thống giao thông, công viên, điện chiếu sáng, dải cây xanh...), góp phần thay đổi diện mạo đô thị du lịch, mang lại hình ảnh mới, nâng cao chất lượng dịch vụ.

Tuy nhiên, việc triển khai trồng cây xanh trên địa bàn chưa đảm bảo, chưa thực sự đẹp, thiếu các loại hình vui chơi giải trí để thu hút khách, đặc biệt là các khu vui chơi giải trí chất lượng cao. Nguồn nhân lực phục vụ du lịch và văn hoá giao tiếp trong hoạt động kinh doanh tuy được tập huấn nhiều nhưng chưa đáp ứng yêu cầu. Ý thức bảo vệ tài nguyên và vệ sinh môi trường của một bộ phận kinh doanh chưa chấp hành nghiêm các quy định của Quận.

Kết quả hoạt động du lịch tại Đồ Sơn thời gian qua chưa tương xứng với tiềm năng, lợi thế do một số nguyên nhân chủ yếu sau: Thứ nhất, chiến lược marketing (của Quận Đồ Sơn) chưa rõ ràng, thậm chí chưa xác định ưu tiên cho thị trường khách hàng nào cả; Thứ hai, hoạt động truyền thông, xúc tiến du lịch còn hạn chế, sức lan toả còn ít; Thứ ba, mối quan hệ giữa các doanh nghiệp du lịch địa phương với các đối tác chưa ổn định và hiệu quả.

Có nhiều nguyên nhân dẫn đến việc yếu kém nêu trên, trước hết là do nhận thức của các cấp, ngành và người dân về vị trí, vai trò, tầm quan trọng của du lịch Đồ Sơn còn hạn chế, đơn giản. Trình độ chuyên môn nghiệp vụ, tay nghề của đội ngũ công nhân viên tại khu du lịch Đồ Sơn còn chưa cao. Chất lượng cơ sở hạ tầng, vật chất kỹ thuật vẫn chưa hoàn thiện, chất lượng phục vụ còn thấp. Bên cạnh đó, phần lớn các hộ kinh doanh chưa có ý thức trách nhiệm đầy đủ với việc xây dựng thương hiệu du lịch, môi trường và văn hoá du lịch Đồ Sơn. Cơ chế ưu đãi đầu tư phát triển du lịch còn hạn chế.

3.4. Giải pháp nhằm giảm thiểu tác động bất lợ của tính mùa vu trong hoạt động du lịch biển Đồ Sơn

Để đảm bảo hoạt động kinh doanh du lịch biển Đồ Sơn đạt hiệu quả cao hơn, cần phải tác động vào mùa vụ du lịch mà cụ thể là cần tác động vào các nguyên nhân gây ra biến động cung - cầu du lịch theo tính mùa vụ. Tuy nhiên việc tác động vào các yếu tố tự nhiên (khí hậu) là rất hạn chế hoặc không có khả năng. Vì vậy, cần tập trung các biện pháp tác động vào nguyên nhân mang tính kinh tế - xã hội. Những tác động này có thể thực hiện được thông qua 2 nhóm giải pháp marketing: 1) nhóm giải pháp tác động tới cầu, chủ yếu là chính sách giá và chính sách truyền thông marketing và 2) nhóm giải pháp tác động tới cung như chính sách sản phẩm, phân phối và các giải pháp khác.

Về truyền thông marketing, cần thực hiện tốt một số nội dung quan trọng: Thứ nhất, quy hoạch được nguồn khách dựa trên cơ sở thu nhập thông tin về tình hình phát triển kinh tế, chính trị, môi trường, tài nguyên du lịch, sự phát triển của ngành du lịch trong nước và quốc tế; nghiên cứu thị trường nhu cầu của nhiều đối tượng du khách khác nhau. Đồng thời tham chiếu hiện trạng chất lượng sản phẩm, tiềm năng phát triển sản phẩm du lịch Đồ Sơn, Hải Phòng nói riêng, các vùng lân cận trong hiện tại 
và tương lai. Thứ hai, thiết kế các nội dung xúc tiến du lịch đúng đối tượng, đúng thị trường thông qua các hoạt động xúc tiến du lịch đa dạng và phù hợp. Thứ ba, tiến hành xúc tiến $d u$ lịch đúng thời gian, đúng nơi và đúng đối tượng cần. Thứ tư, tổ chức đánh giá kết quả thực hiện và có biện pháp điều chỉnh thường kịp thời, cập nhật thông tin mới về hình ảnh, sản phẩm du lịch, đáp ứng liên tục, kịp thời công tác xúc tiến du lịch. Thứ năm, đảm bảo huy động kinh phí quảng bá và thực hiện công tác PR. Kinh phí được trích ra từ doanh thu du lịch tăng thêm hàng năm hoặc/ và các tổ chức kinh doanh du lịch, có hàng hóa cung cấp chủ yếu cho du lịch Đồ Sơn tài trợ.

Về chính sách giá, vẫn tuân theo quy luật cung cầu nhưng cố gắng giảm bớt sự chệnh lệch giữa chính vụ và trái vụ, đặc biệt là do nguyên nhân "phi kinh tế". Chính sách "chiết khấu" hay "hoa hồng" cần linh hoạt theo thời vụ, thời điểm...

Về chính sách sản phẩm, tiếp tục nâng cao chất lượng các sản phẩm hiện có như: du lịch tắm biển, nghỉ dưỡng; tham quan di tích văn hoá lịch sử, danh thắng; du lịch thể thao; mua sắm, thương mại, công vụ và hội nghị, hội thảo... đồng thời phát triển các sản phẩm du lịch tiềm năng như: du lịch sinh thái và tham quan các làng nghề thủ công mỹ nghệ, chế biến hải sản, thăm thân nhân và kết nối tour trong và ngoài thành phố... Chú trọng chất lượng các sản phẩm hải sản tươi, khô, nước mắm....

Khai thác tiềm năng du lịch nhân văn là một trong những giải pháp khắc phục tính mùa vụ trong hoạt động du lịch biển Đồ Sơn. Tổ chức hội nghị, hội thảo, triển lãm, tập huấn nghiệp vụ, các hội chợ, các cuộc triển lãm chuyên ngành du lịch...cũng góp phần thu hút khách vào thời điểm "thấp vụ". Quan tâm hơn đến việc tổ chức các sự kiện trên cơ sở đầu tư cơ sở vật chất, hoàn thiện và nâng cấp các khu du lịch hiện có, đầu tư xây dựng một số khu du lịch mới với các sản phẩm du lịch đa dạng, có sức hấp dẫn cao để thu hút khách du lịch trong nước và nước ngoài.

Đầu tư xây dựng mới, khôi phục các ngành nghề truyền thống, làng nghề sản xuất, chế biến thủy hải sản, đầu tư hoàn thiện hệ thống cung cấp nước sạch, ổn định điện sinh hoạt, điện kinh doanh, khuyến khích các đơn vị, cá nhân đầu tư vào lĩnh vực vận chuyển khách du lịch.

Quan tâm hợp tác, liên kết, mở rộng các tour, tuyến mới phục vụ nhu cầu tham quan của du khách. Khai thác giá trị văn hoá phi vật thể để tạo ra các sản phẩm du lịch đặc sắc, hấp dẫn, củng cố các tuyến du lịch hiện có và từng bước triển khai các tuyến du lịch mới. Nâng cao chất lượng dịch vụ du lịch, đặc biệt là dịch vụ nghỉ dưỡng, ăn uống, vui chơi giải trí.

\section{Về chính sách phân phối}

Tiếp tục phát huy các mối quan hệ với các công ty lữ hành nói chung và các công ty $\mathrm{du}$ lịch trên địa bàn Hải Phòng nói riêng. Liên kết phát triển du lịch Hải Phòng với các tỉnh đồng bằng sông Hồng. Phát triển quan hệ kinh doanh với Saigontourist trong việc khai thác các dòng sản phẩm đa dạng dành cho khách du lịch trong nước và quốc tế đến Việt Nam theo đường bộ, hàng không và đường thủy.

Cố gắng chuyển từ quan hệ hợp tác sang quan hệ đối tác và đối tác chiến lược nhằm đảm bảo nguồn khách theo thời gian trong năm.

\section{Về chính sách nguồn nhân lục}

Tổ chức điều tra khảo sát thực tế thực trạng chất lượng nguồn nhân lực của toàn ngành du lịch Đồ Sơn, từ đó phân ra loại nào cần được đào tạo mới, đào tạo lại hay bồi dưỡng thêm phù hợp với trình độ của từng nhóm đối tượng với nhu cầu trong từng hạng mục của ngành.

Quận cần sắp xếp lại tổ chức bộ máy và đội ngũ cán bộ toàn ngành, ưu tiên bố trí cán bộ lãnh đạo và quản lý ngành có trình độ, có tâm huyết và quyết tâm cao đối với sự phát triển của ngành, để chỉ đạo và phối hợp tìm kiếm hợp tác các chuyên gia, tư vấn du lịch, lập kế hoạch tổ chức thực hiện đào tạo, bồi dưỡng nâng cao chất lượng của đội ngũ quản lý du lịch, lao động và cộng đồng nhân dân ở Quận vào ngoài mùa vụ để có một đội ngũ nhân sự chuyên nghiệp, kỹ năng tay nghề cao phục vụ trong mùa vụ. 


\section{Bảo duõng và nâng cấp chất luợng khách san du lich}

Trước mắt Quận nên có phương án khuyến khích, hỗ trợ cho các khách sạn, nhà nghỉ, nhà hàng, chú trọng công tác duy tu bảo dưỡng cơ sở, trang thiết bị phục vụ du lịch trong mùa vắng khách, để vừa bảo quản tài sản cho chính bản thân doanh nghiệp đó, đồng thời sẵn sàng đáp ứng tốt nhu cầu du khách bất kỳ thời điểm nào trong năm.

Khuyến khích, hỗ trợ các cơ sở có từ 20 phòng nghỉ trở lên đầu tư nâng cấp để đạt tiêu chuẩn 2 sao, và khách sạn có từ 50 phòng trở lên đạt tiêu chuẩn 3 sao, 4 sao, đáp ứng kịp thời nhu cầu của khách hàng ngày càng cao. Đặc biệt cần có nhiều khách sạn đạt tiêu chuẩn 3 sao có quy mô từ 150 phòng trở lên và có nhiều dịch vụ bổ sung có chất lượng cao.

\section{Kết luận}

Đồ Sơn là một trong những điểm đến $\mathrm{du}$ lịch có tính hấp dẫn cao nhất ở Bắc Bộ với tài nguyên du lịch tự nhiên đa dạng, phong phú; các tài nguyên nhân văn có tính đặc sắc.

Hoạt động du lịch ở Đồ Sơn có tính mùa vụ điển hình, được hình thành bởi các yếu tố tự nhiên, kinh tế - xã hội, trong đó điều kiện khí hậu nhiệt đới ẩm gió mùa, có mùa đông lạnh do chịu tác động của gió mùa đông bắc đóng vai trò quan trọng nhất.

Tính mùa vụ tác động đến hoạt động du lịch biển Đồ Sơn theo hai hướng tích cực và tiêu cực:

Huớng tác động tích cưc: Vào mùa vụ du lịch, khi lượng khách tăng lên một cách đáng kể ở các khu du lịch thì các nhu cầu về hàng hoá và dịch vụ cũng tăng lên rất cao. Điều đó dẫn tới các cơ sở kinh doanh (nhà nước và tư nhân) có rất nhiều cơ hội để mở rộng sản xuất kinh doanh, họ buộc phải tuyển thêm lao động, mở nhiều loại hình dịch vụ đa dạng, kết quả là làm đa dạng các loại hình dịch vụ, tạo thêm công ăn việc làm, tăng thu nhập cho doanh nghiệp và cho ngân sách nhà nước. Mùa vụ du lịch ở các khu du lịch tạo ra "cầu" tương đối về lương thực, thực phẩm và hàng hoá đã thúc đẩy các ngành kinh tế khác phát triển và giải quyết thêm nhiều công ăn việc làm cho các lực lượng lao động gián tiếp khác.

Huớng tác động tiêu cực: Thời điểm "trái vự”, ít khách nên dẩn tới nguy cơ xuống cấp cơ sở hạ tầng, lãng phí nguồn nhân lực, nguồn thu nhập rất bấp bênh. Việc tập trung khách vào mùa cao điểm cũng làm giảm sự hài lòng của du khách do khả năng đáp ứng nhu cầu của $d u$ khách không được chu đáo. Du khách sẽ không được phục vụ trong điều kiện tốt nhất, giá cả lại đắt hơn, đi lại khó khăn hơn do sự quá tải... Tập trung khách vào mùa cao điểm còn gây sức ép lớn đến môi trường do nhu cầu sử dụng tài nguyên (năng lượng, nước...) tăng cao, lượng nước thải, rác thải cũng tăng đột biến vào mùa cao điểm.

Nhằm khắc phục các tác động tiêu cực liên quan với tính mùa vụ trong phát triển du lịch biển Đồ Sơn, cần thực hiện 2 nhóm giải pháp marketing: 1 / nhóm giải pháp tác động tới cầu, chủ yếu là chính sách giá và chính sách truyền thông marketing và $2 /$ nhóm giải pháp tác động tới cung như chính sách sản phẩm, phân phối và các giải pháp khác.

\section{Tài liệu tham khảo}

[1] Commons, J. and Page, S. (2001), Managing Seasonality in Peripheral Tourism Regions: The Case of Northland, New Zealand, In T. Baum and S. Lundtrop (eds.), Seasonality in Tourism, New York, Pergamon, Amsterdam, pp.153-172.

[2] Manning, R.E. and Powers, L. (1984), Peak and Off Peak Use: Redistributing the Outdoor Recreation/Tourism Load, Journal of Travel Research, 23(2): 25-31.

[3] Viện Nghiên cứu Phát triển Du lịch (1998), "Nghiên cứu ảnh hưởng của tính mùa vụ du lịch đến hoạt động du lịch ở Việt Nam", Báo cáo Đề tài NCKH cấp Bộ.

[4] Du lịch miền Trung: Tìm cách phá thế "mùa vụ" (2014), Cổng tin điện tử Chính phủ.

[5] Vương Lôi Đình, Đổng Ngọc Minh (2002), Kinh tế du lịch và Du lịch học, NXB Trẻ, TP Hồ Chí Minh.

[6] Philip Kotler (2009), Quản trị Marketing, Nhà xuất bản Lao động xã hội

[7] Phòng VHTT - DL (2011-2015), Báo cáo tổng kết hoạt động du lịch năm 2011, phương hướng nhiệm vụ 2012, UBND Quận Đồ Sơn.

[8] Tổng cục du lịch (2011), Số liệu thống kê du lịch Đồ Sơn, Hải Phòng. 


\title{
Seasonality and Marketing Solutions for Sustainable Development of Do Son Coastal Tourism
}

\author{
Vu Tri Dung, Pham Thi Kim Thanh \\ National Economics University, 207 Giai Phong, Hai Ba Trung, Hanoi, Vietnam
}

\begin{abstract}
The marine economy in general and coastal tourism in particular play an important role in Vietnam. Due to the tropical monsoon climate with a cold winter, coastal tourism in the Northern provinces has seasonality and faces significant difficulties compared to the Southern provinces. Seasonality is a concept that has been well perceived and studied in both the tourism literature and tourism businesses. It is necessary to cary out in-depth researches to provide scientific arguments on the nature, causes and effects as well as solutions to minimize the negative impact of tourism seasonality.

This article focuses on analyzing and evaluating the effects of seasonality on the coastal tourism business in Do Son, Hai Phong. Based on that, the authors also propose some marketing solutions to overcome the negative effects of seasonality in terms of balancing demand and supply in both long and short run.
\end{abstract}

Keywords: Marketing in tourism, the seasonality, tourism services. 